\title{
ARTIKKEL ÕNNESOOVIDEGA. KOMITATIIVI FUNKTSIOONIDEST ERI AEGADE JA REGISTRITE EESTI KIRJAKEELES
}

\author{
Helle Metslang, Külli Habicht, Tiit Hennoste, Anni Jürine, \\ Kirsi Laanesoo, David Ogren \\ Tartu Ülikool
}

\begin{abstract}
Ülevaade. Eesti komitatiiviga väljendatavad koosesinemisfunktsioonid moodustavad võrgustiku, mille keskmes on kaks prototüüpset funktsiooni, KAASNEMINE ja VASTASTIKUSUS. 17.-18. sajandi kirjakeele komitatiivi funktsioonid esindavad KAASNEMISE haru, 20. sajandi materjalis domineerib VASTASTIKUSUS. Komitatiivi funktsioonid on sajandite jooksul järjest laienenud. Tänapäeva kirjakeele materjalis on esindatud nii KAASNEMISE kui ka VASTASTIKUSUSE haru, mõlema kasutustendentsid seostuvad tekstiliigi funktsionaalse ja sisulise eripäraga. Kontaktkeeltest sarnaneb eesti komitatiivi funktsioonivõrgustik enim saksa keele ja vähim soome keele võrgustikuga.
\end{abstract}

Märksõnad: komitatiiv, koosesinemine, funktsioonid, varieerumine, register, kirjakeel, eesti keel

DOI: https://doi.org/10.12697/jeful.2017.8.1.09

\section{Sissejuhatus}

Eesti komitatiivi tunneme grammatisatsiooni kuldnäitena: kaassõnaühendi kujunemine käändelõpuks on jälgitav vana kirjakeele tekstides. Nüüdseks on komitatiivist kujunenud laiade kasutusvõimalustega kääne. Senised uuringud ja ülevaated käsitlevad eesti komitatiivi mõningaid funktsioone, samas komitatiivi funktsioonide, nende kujunemise ja seoste lähem analüüs seni puudub. Siinne artikkel käsitleb eesti komitatiivi funktsioone ja süntaktilisi vormitüüpe kuues tekstiliigis läbi viie sajandi. Meid huvitavad järgmised küsimused. a) Millised on eesti komitatiivi kesksed ja perifeersed funktsioonid ja milliseid süntaktilisi vormitüüpe komitatiivid esindavad? b) Kuidas komitatiivivormide funktsioonid ja vormitüübid omavahel seostuvad? c) Milliste funktsioonidega komitatiivivormid on eri tekstiliikides ja eri ajajärkudel kasutusel? d) Millist mõju on komitatiivi funktsioonidele võinud avaldada kontaktkeeled? 


\section{Komitatiivist eesti keeles}

Kõigepealt anname lühiülevaate eesti komitatiivi kujunemisest ja senistest käsitlustest.

Eesti $g a$-lõpuline komitatiiv on hilise kujunemisega kääne, mis on asendanud eesti keeles läänemeresoome $n e$-komitatiivi. (Tõenäoliselt on läänemeresoome keelte ne-komitatiiv, instruktiiv ja essiiv ühise päritoluga, vt Sirola-Belliard 2016: 59.)

Kaasaütleva käände teke on seotud kaassõnaliste väljendusvõimaluste levikuga varases läänemeresoome keeles. Nimisõna *kansa 'rühm, hulk > rahvas' latiivivormist *kansak kujunes grammatiseerumise käigus tagasõna, mida kasutati koos genitiivis käändsõnaga. Grammatiseerumisega kaasnes sõna häälikuline kulumine, mille tulemusel jäi tagasõna kujuks kaas. (Rätsep 1979: 77-78) Sellisena on see ulatuslikult kasutusel ka 16.-17. sajandi tekstides. Tagasõna edasist arengut on võimalik jälgida kirjakeele allikates. Kõigepealt toimus lühenemine $k a a s>k a a>k a$ ja pärast tagasõna liitumist kaassõnaga, s.t käändelõpuks kujunemist, asendati vokaalidevaheline $k g$-ga. (Rätsep 1979: 78, Habicht 2000: 44-48, vt ka Ehala 1996: 382) Kui 17. sajandi lõpul on põhjaeestilistes tekstides komitatiivi väljendamisel valdav veel kaas-tagasõna, siis 18 . sajandi esimese poole olulised piiblitõlked (1715. a uus testament ja 1739. a täispiibel) sisaldavad juba käändelõppu -ga. Seega on lõplik üleminek kaassõnalt käändelõpule kirjakeeles küllaltki kiire.

Vanast $n e$-komitatiivist on tänapäeva keeles säilinud vaid mõned selle tunnuse kivinenud kuju sisaldavad adverbid, nt koguni, iganes, üksnes, iseäranis. Üksikuid ne-komitatiivi vorme leidub rannikumurde rahvalauludes, nt poiginesa, sulasinesa. (Rätsep 1979: 77)

Eesti keele olulistes ülevaateteostes tuuakse esile komitatiivi erinevaid funktsioone. Johannes Valgma ja Nikolai Remmeli käsiraamatus "Eesti keele grammatika" (1968: 66) on nimetatud koosoleminE (Mari läks (koos) Jüriga kinno), ABINõU (Mees kaevas labidaga maad), TEOVIIS ja PÕHJUS (Laps vaatas mõtliku näoga), AEG (Ma lõpetan selle töö kahe päevaga) ning LIGEM ISELOOMUSTUS ehk OSA TERVIKU KÜLJES (poiss, nimega Jaak).

"Eesti keele grammatika" morfoloogiaosas (EKG I: 60) on esitatud põhiliselt samad funktsioonid. Kesksetena tõstetakse esile KAASASOLU (= KOOSOLEMINE) ja VAHENDI/ABINÕU väljendamist. Nende kõrval märgitakse VIISI või SEISUNDI (= TEOVIIS) ning AJA väljendamist ja mõne verbi rektsioonilise laiendi puhul ka selle väljatoomist, millele tegevus 
on suunatud (uue olukorraga harjuma). "Eesti keele grammatika" süntaksiosas (EKG II: 55-135) on komitatiiv välja toodud mitme määruse vormistajana (kaasnemis-, vahendi-, viisi-, aja-, seisundi-, põhjus-, tingimus-, sõltuvusmäärus). Selle kõrval on mainitud ka ekvatiivtarindit (isaga sarnane), atribuuti (pika sabaga koer) ja öeldistäidet (koer on pika sabaga).

Eesti keele süntaksi tervikkäsitluses "Eesti keele süntaks" (Erelt ja Metslang, toim 2017) nimetatakse EKG-ga võrreldes samad funktsioonid, lisaks kirjeldatakse põhjalikult komitatiivi suhet rinnastusega.

Komitatiivi kasutust käsitlevates üliõpilasuurimustes (Vals 1953, Sakamoto 1995) tuuakse lisaks grammatikates nimetatutele välja semantilise овJекTI (pahandasin temaga) ja SEOSE väljendamine (on raskusi matemaatikaga).

Kõigis käsitlustes tõusevad esile kesksed funktsioonid (KOOSOLEMINE-KAASASOLU, VAHEND jm), samas vaadeldakse mitmeid kasutusjuhte lihtsalt rektsioonist tingitutena. Sel moel jäävad samad, kuid eri lauseliigendustasanditel avalduvad funktsioonid üksteisest lahku (nagu lausemäärus sarnaneb isaga, adjektiivi laiendav määrus isaga sarnane ja täiend sarnasus isaga).

\section{Komitatiivi kategooriast ja tähendusfunktsioonidest}

Keeletüpoloogias mõistetakse komitatiivi all funktsionaalgrammatilist kategooriat, mille keskseks funktsiooniks on KAASNEJA märkimine. Selle kategooria vormivahendiks võivad olla kääne, kaassõna, aga ka muud keelelised vahendid. Komitatiivi kategooria funktsioonidest huvipakkuvaim on olnud VAHENDI (eriti Balti areaali keeltes) ja rinnastuse väljendamine (Stolz 2001, Stolz jt 2006, Stassen 2000).

Komitatiivi kategooria seostub laia funktsionaalse väljaga, mida Christian Lehmann ja Yong-Min Shin (2005) nimetavad koosesinemiseks (concomitance) ning mille eri alltüüpide väljendamine võib keeltes jaguneda mitme vormistusviisi vahel: nimisõna käändevorm, kaassõnafraas, komplekslause, verbituletus (vt ka Siegl ja Kehayov 2010).

Koosesineja on lausega tähistatud situatsiooni osaline, mis ei suhestu mitte üksnes predikaadiga, vaid ka teise osalisega, tavaliselt tegevussubjektiga (Mari läks Jüriga kinno) või tegevusobjektiga (Ema saatis Mari koos Jüriga kinno). Koosesinemissuhe võib sarnaneda rinnastusega: kaks referenti täidavad situatsioonis sama rolli, on nt mõlemad 
agentideks (Mari ja Jüri läksid kinno) või patsientideks (Ema saatis Mari ja Jüri kinno). Erinevalt rinnastusest on koosesinemissuhte korral üks koosesineja (põhiosaline) esile tõstetud ja seda vormistab alus või sihitis, teine (kaasosaline) on vormistatud tavaliselt komitatiivse määrusena ning jääb sellisena tagaplaanile (Erelt 2017).

Koosesinejal on rohkesti semantilisi alltüüpe, mis erinevad mitme tunnuse poolest:

1) koosesineja entiteedi tüüp (olend/asi, omadus, situatsioon jne) ja tema koht elusushierarhias (inimene, elusolend, eluta objekt, aine, abstraktmõiste, situatsioon);

2) koosesineja suhe situatsiooniga (kontrollib situatsiooni või mitte, olles vastavalt tegevussubjekt või -objekt);

3) koosesinejaga seostuva põhiosalise aktiivsus-passiivsus situatsioonis;

4) predikaadiga seostuva rolli spetsiifilisuse määr (nt sõiduvahend: sõidab autoga).

Lehmann ja Shin (2005) eristavad nimetatud tegureid arvestades 16 keele materjali põhjal kaheksat koosesinemisfunktsiooni. Illustreerime neid siinkohal eesti keele näidetega.

1) KAASLANE (Jüri läks Mariga kinno)

2) PARTNER (Jüri abiellus Mariga)

3) LIIKUMISVAHEND (Mari sõidab jalgrattaga)

4) VAHEND (Jüri lõhub kirvega puid)

5) MATERJal (eesti keeles elatiiv, nt Poiss tegi paberist laeva)

6) VIIS (läheb lauluga)

7) ASJAOLU (Halva ilmaga me õue ei lähe)

8) LÄHEDUS, OMANDUS (kaaslasega külaline, nokaga müts)

Nagu näeme, vormistab eesti keeles kõiki neid tähendusi peale MATERJALI kaasaütlev kääne.

\section{Materjal ja meetod}

Meie analüüsitavad tekstid kuuluvad kuude liiki: 1) 17.-18. sajandi usutekstid, 2) 18. sajandi õpetlikud tekstid, 3) 20. sajandi lõpu ilukirjandustekstid, 4) 21. sajandi alguse ajakirjandustekstid, 5) 21. sajandi netikommentaarid ja 6) 21. sajandi netidialoogid. 
17.-18. sajandi tekstidest on Tartu Ülikooli vana kirjakeele korpusest $^{1}$ uurimiseks valitud vaimulik kirjandus (usutekstid ehk jutlused, kirikuraamatud, piiblitõlked) ja 18. sajandi õpetlik jutukirjandus, mis sisaldab tõlkemõjulisi poolilmalikke tekste. Valitud materjal pakub representatiivse läbilõike tollasest kirjakeelest ning selles on esindatud mõjukamad tekstid, mis võisid kujundada omaaegset keelekasutust.

20.-21. sajandi trükitekstide keelest võtsime uurimiseks Tartu Ülikooli eesti keele koondkorpuse 1990.-2000. aastate ilukirjanduse ja ajakirjanduse materjali. Mõlemad tekstikogumid on valitud omas liigis suhteliselt ühtlasest materjalist. Ilukirjandustekstide materjal pärineb allkorpuse "Eesti ilukirjandus 1990" 2 realistliku proosa tekstidest. Ajakirjandustekstide materjal pärineb nädalalehe Maaleht tekstidest, mis esindavad ilukirjanduse materjaliga sama aega. ${ }^{3}$

Netikeelest valisime analüüsimiseks 2000.-2010. aastate netidialoogid ja -kommentaarid. Dialoogid pärinevad Tartu Ülikooli koondkorpuse $^{4}$ netidialoogide allkorpusest ning kommentaarid Delfi ja Postimehe netiportaalide kommentaariumidest. Dialoogid on argivestlused tuttavate ja sõprade vahel ning sisaldavad nii infovahetust kui ka sotsiaalsele suhtlusele orienteeritud lobisemist (ingl small talk). Tekstid valisime selliselt, et sama isik ei oleks esindatud kaks korda. Kommentaariumitekstid on anonüümsed kommentaarid mõne uudisportaalis avaldatud lähteteksti kohta. Valimisse on võetud eriteemalised kommentaarid, et vältida konkreetse teema ja sellega seostuvate näidete üleesindatust. ${ }^{5}$

Igast tekstiliigist võtsime analüüsimiseks 100 juhuvalikuga otsitud komitatiivivormi, kokku 600 näidet. Analüüsitud tekstid erinevad kolme parameetri poolest.

Esimeseks eristajaks on tekstide vanus. Vana kirjakeele tekstid pärinevad 17.-18. sajandist, ülejäänud tekstid on tänapäevased. Netitekstid esindavad sealjuures selliseid tekstiliike, mida varasemas keelelises suhtluses ei esinenud.

Teiseks seostuvad eri tekstiliigid erinevate kontaktkeeltega. Vana kirjakeele tekstid olid saksa keele mõjuväljas, mis toetas kuni

\footnotetext{
1 http://www.murre.ut.ee/vakkur/Korpused/. Vaadatud 10.01.17.

2 http://www.cl.ut.ee/korpused/segakorpus/eesti_ilukirjandus_1990/. Vaadatud 10.01.17.

3 http://www.cl.ut.ee/korpused/segakorpus/maaleht/. Vaadatud 10.01.17.

4 http://www.cl.ut.ee/korpused/segakorpus/. Vaadatud 10.01.17.

5 Kommentaariteemade seas on reageerimine kirjaniku surmakuulutusele, nn Ukraina küsimus, palaviku mõõtmise vahendid, sotsiaaldemokraatide poliitika, laste ohtlik mäng raudteel jm.
} 
17. sajandi lõpukümnenditeni saksa mit-konstruktsiooniga võrreldavat kaassõnalist komitatiivikonstruktsiooni (silmade kaas 'silmadega'). Ka komitatiivi kasutusfunktsioonide puhul võib oletada saksa keele eeskuju. Tänapäeva netikeelt mõjutab inglise keel, mille with-ühendi funktsioonid sarnanevad eesti komitatiivi omadega. Seega võib oletada, et inglise mõju toetab komitatiivi väljakujunenud kasutust.

Kolmandaks erineb tekstide laad ja tüüpiline temaatika. Nii on tõlkelistes usutekstides kasutusel keerukad lausekonstruktsioonid ja religioosne retoorika, netidialoogides käsitletakse rohkem suhtlusega seostuvat temaatikat, ajakirjanduses ja kommentaarides tegutsemist ja erinevaid olukordi.

Analüüsi käigus jagasime komitatiivinäited kahe parameetri alusel. Esiteks rühmitasime näited vastavalt käändevormi semantilisele funktsioonile, sõltumata nende süntaktilisest realisatsioonist. Analüüsi lähtekohaks võtsime kõik eesti allikates ning Lehmannil ja Shinil (2005) välja toodud funktsioonid, millele lisasime kategooria "Muu", kuhu paigutasime esialgu need näited, mis kategooriate alla ei mahtunud. Seejärel analüüsisime "Muu" lahtri näiteid. Kokkuvõttes eristasime empiirilise materjali põhjal 12 komitatiivi tähendusfunktsiooni. Teiseks analüüsisime komitatiivivormide lauseliikmelisust, tuues välja komitatiivi süntaktilised vormitüübid (määrus, öeldistäide, täiend jm). Kvalitatiivsele analüüsile järgnes materjali kvantitatiivne analüüs.

\section{Eesti komitatiivi funktsioonid}

Siinses jaotises toome välja oma uurimuses leitud eesti komitatiivi funktsioonid, toetudes analüüsil ennekõike Lehmanni ja Shini (2005) käsitlusele, samuti eesti komitatiivi senistele kirjeldustele.

Koosesinemissuhte prototüüpsed, vähim markeeritud, lihtsad ja põhilised juhud on kaasnemissuhe KAASNEMINE (Mari läks Jüriga kinno) ja vastastikuse tegevuse suhe vaSTASTIKUSUs (Mari abiellus Jüriga). Nendes funktsioonides on koosesinemissuhte osalised (komitatiivis vormistatud kaasosaline ja temaga seostuv põhiosaline) samal tasemel elusushierarhias, situatsiooni kontrollimises ja aktiivsuses. Prototüüpsete funktsioonide korral saab põhiosalist ja kaasosalist seostada ka rinnastuse abil, nt Mari ja Jüri läksid kinno, Mari ja Jüri abiellusid. (Vt Erelt 2008, 2017.)

Ülejäänud funktsioone võib käsitleda kui prototüüpsetest funktsioonidest tuletatud ja keskmest kaugemaid. Neid iseloomustab järjest suurem elususe ja aktiivsuse tasemete erinevus ja seega rinnastamise 
võimaluste vähenemine (võRdLus: Mari on Jüriga ühepikkune - Mari ja Jüri on ühepikkused; Mari on sarnane Kunksmooriga - 'Mari ja Kunksmoor on sarnased; VAHEND: Mari tõi kannuga vett - *Mari ja kann tõid vett).

Järgnevalt kirjeldame erinevaid funktsioone täpsemalt.

1. KaASNemine (KaAslane, Koosolemine, KaASasolu) on funktsioon, mille puhul teise olendi või objektiga kaasnev olend või objekt täidab situatsioonis sama rolli kui temaga seostuv põhiosaline. Põhiosaline ja kaasosaline ei erine üldjuhul ei rolli, aktiivsuse ega elususe poolest, vaid üksnes esiletõstetuselt: põhiosaline nagu näites (1) perenaine Mahta ja näites (2) täitetoimik on esiletõstetum kui komitatiivis kaasosaline lapsed ja avaldus.

(1) Perenaine Mahta ei saanud lastega kunagi vanematekoju minna, sest isa oli kuri. (AJA)

(2) Täitetoimik antakse uuele kohtutäiturile koos avaldusega (AJA)

Prototüüpse kaasnemissuhte komitatiiv sobib kasutamiseks kaassõnaga koos: Perenaine Mahta ei saanud koos lastega kunagi vanematekoju minna (vrd näide 1).

Lehmanni ja Shini (2005: 37) eeskujul käsitame kaasnemissuhtena ka juhte, kus põhi- ja kaasosaline erinevad elususe poolest ja seetõttu ka situatsiooni kontrollimise võimelt (3).

(3) Mitte et mu oma õpetaja vilets oleks olnud, kaugel sellest, aga kui inimene tahab rohkem tunde võorkeeltega veeta, miks mitte. (KOMM)

2. VASTASTIKUSUS (PARTNER) on vastastikuses tegevuses osalemine, mida vormistavad tegevussubjektide vastastikust tegevust väljendavad verbid, nt abielluma, vaidlema, kaklema, suhtlema (4), aga ka tegevusobjektide vastastikusust väljendavad liitma, ühendama jm (5). Sellised verbid nõuavad erinevalt KAASNEMISEST kahte osalist, mis on elususe, kontrolli ja aktiivsuse poolest võrdväärsed. Selle funktsiooni puhul kaassõna koos lausesse lisada ei saa. ${ }^{6}$

6 Huno Rätsep (1978: 224-225) toob eesti keele lausemallide käsitluses eraldi rühmana välja retsiprookverbide (nt kohtuma, võrdsustama) lausemallid, mille puhul saab tegevussubjekte või -objekte vormistada mitmel viisil, sealhulgas ühte neist komitatiiviga väljendades või mõlemaid rinnastades. Rätsep käsitleb samas rühmas ka neile lähedasi juhtumeid, nagu Tasapind asetseb liikumissuunaga risti. Viimased kuuluvad siinses liigituses võRDLUSE funktsiooni alla. 
(4) Aga ta suhtleb oma endise kaasaga edasi. (AJA)

(5) Osa Peetri ja Voka vallast liideti Vaivara vallaga. (AJA)

3. VõrduUs (sh KÕRVUTAMine, SAMASTAMINE) on lähedane VASTASTIKUSUSELE. Siin võrreldakse kahe osalise omadusi või tegevust, osalised on üldjuhul sama tüüpi entiteedid ega erine ka aktiivsuse poolest (6 ja 7).

(6) Ja kui ta oli oma muresid pihtinud, oli arst kohe neid enda omadega võrrelnud ja öelnud, et ta ei saa oma õnnetustest kunagi üle. (ILU)

(7) Kirvega tuleb lüüa soonipidi ja mitte nendega risti. (ILU)

Kui võrdlusalune entiteet on võrreldavast entiteedist elusushierarhias madalam (nt inimene - eluta objekt), võib koosesinemissuhtele viitava komitatiivi asemel esineda allatiiv (poiss sarnaneb oma isaga, aga poiss sarnaneb lumememmega/lumememmele).

4. Suhestamine on vastastikususest välja kasvanud entiteetidevahelise täpsemalt määratlemata seose väljendamise funktsioon (8).

(8) Ilmatark Ain Kallis: Nii suurtel üleujutustel on palju põhjusi, osa neist on seotud kliima soojenemisega. (AJA)

5. TegevusobJekt on funktsioon, millega väljendatavat suhet osaliste vahel võib käsitada KAASNEMISEL põhinevana. Põhi- ja kaasosalise suhe on siin muutunud semantiliste makrorollide suhteks: põhiosaline on tegevussubjekt, kaasosaline tegevusobjekt (nõidusega ei naljatata, testimisega alustasime aastal 2010). Tüüpjuhul paikneb kaasosaline ka elusushierarhias põhiosalisest madalamal (9).

(9) Vaevalt olin saanud lausega lõppu, kui ta rääkis juba sellest tuttavast, kes olnud ENSV ajal KGB agent. (ILU)

6. Neutraalne osaline on juhtum, mille korral põhiosaline (tegevussubjekt) situatsioonis puudub, komitatiiv märgib ainsat tuumstruktuuri osalist, seega olulisimat osalist (10).

(10) Aitab, aitab juba, ütlesin, nendega on lugu täiesti selge. (ILU) 
SuHESTAMISE, TEGEVUSOBJEKTI ja NEUTRAALSE OSALISE funktsioonid on komitatiivi jaoks perifeersed ning näitavad komitatiiviga väljendatud tähendusfunktsiooni ebamäärastumist ja komitatiivi pürgimist lause kesksete positsioonide poole. TegevusobjeKti vormistab lauses tavaliselt sihitis (mind mõjutati), NEUTRAALI alus (nende lugu selgub). Komitatiiv ei ole nende rollide keskne väljendaja. SuHESTAMISE funktsiooni saab väljendada mitmeti (rinnastusega, kaassõnaga, põimlausega) - siin pakub komitatiiv üht lihtsat grammatilisemat väljendusviisi.

7. VAHEND (ABINÕU, INSTRUMENT) kasvab välja KAASNEMISE spetsialiseerumisest metafoori VAHEND ON KAASLANE kaudu (vt Lakoff ja Johnson 2011 [1980]: 169-171). Tüüpjuhul on põhiosaline aktiivne elus agent, kellel on kontroll tegevuse üle; kaasosaliseks on ese või aine, millel kontrolli pole (11). Poliitik saavutas tulihingelise kõnega rahva poolehoiu. Põhiosaline võib olla ka eluta, nt Tuisk kattis maa lumega. VAHENDI erijuhuks on EESMÄrK või PÕHJUs, nt Poliitik kõneles tulihingeliselt eesmärgiga rahva poolehoidu saavutada; Poliitiku tulihingelise kõnelemisega tuli ka rahva poolehoid.

(11) Kahn lööb situatsiooni rusikatega puhtaks. (AJA)

8. LiIKUMISVAHEND on VAHENDI edasine spetsialiseerumine (12) või ka VAHENDIGA analoogiline nihe kaasnemissuhtest. LiIKUMISVAHENDIT võib vahel käsitada ka KOHANA ja vormistada kohakäänete abil (sõidab laeval, lennukis).

(12) Vanaema sõitis trammiga läbi heinamaa ja sälud jooksid lehvivate lakkade välkudes traavi. (ILU)

9. ViIs (TEOVIIS, SEISUND) sarnaneb VAHENDIGA, kuid kaasosalise entiteet ei ole siin mitte asi või aine, vaid kaasnev seisund või tegevus, mis iseloomustab lausega väljendatud tegevust, nt ütles vihaga, tuli lauluga, kuulas andumusega (13).

(13) Nüüd kuulas ta plaati erilise andumusega ning teise laulu vivere ja eelviimase laulu miserere omandasid ta kõrvus saatusliku kõla. (ILU)

10. Asjaolu (seos) on kaasnev situatsioon, mis võib lause põhisituatsiooni suhtes olla PÕHJUs, TINGIMUS või TAGAJÄrg (Palavikuga võib otsmik niiske olla; Suure kiirustamisega unustasin telefoni koju). Seda funktsiooni võib käsitada kaasnemissuhte erijuhuna, kus kaasnevateks entiteetideks on situatsioonid. AsJaOLu tähistavad olukorda või 
situatsiooni väljendavad sõnad, nagu kiirustamine, avamine, palavik (14).

(14) Eesti ühepoolse avamisega anti turud väliskonkurentidele. (AJA)

11. Omandus (Lähedus, Ligem iseloomustus) on sama või lähedast tüüpi referentide vaheline otseseos, nt osa ja terviku suhe (punase katusega maja) või muu kokkukuuluvus (daam koerakesega). Erinevalt muudest funktsioonidest, mida tüüpiliselt väljendavad määrused, on OMANDUST väljendav komitatiiv täiendiks nimisõnafraasi sees (15) või öeldistäiteks (16).

(15) Nähtud on isegi veealuste tiibadega surfilaudu ja muid kummalisi lennumasinaid. (AJA)

(16) "Kui ühe krundiga on tehingud tehtud, siis kas kõrvalasuv maatükk on madalama väärtusega sel lihtsal põhjusel, et teda pole veel müüdud?" (AJA)

12. AEg on komitatiivi puhul perfektiivse situatsiooni lõpulejõudmisega seostuv ajavahemik (17). Seda funktsiooni võib käsitada suHEsTAMISE spetsialiseerumisena.

(17) “Tore, et kodunt metsa saab jalgsi viie minutiga," ütleb poeet. (AJA)

Siinses analüüsis välja toodud 12 funktsioonist on varasemates eesti keele ülevaadetes esindatud eri nimetuste all KAASNEMINE, VAHEND, VIIS, OMANDUS ja AEG. Üliõpilasuurimustes leiduvad lisaks TEGEVUSOBJEKT ja ASJAOLU, mida grammatikates on kirjeldatud määruste all. Meie oleme Lehmanni ja Shini (2005) järgides eristanud veel LIIKUMISVAHENDI ja VASTASTIKUSUSE (eesti grammatikas on neidki kirjeldatud määruse all). Lisaks oleme tõlgendanud eraldi funktsioonidena võRDLUST, SUHESTAMIST ja NEUTRAALSET OSALIST, mida varem on käsitletud samuti määruste all.

Kokkuvõttes võime öelda, et komitatiivi funktsioonid koonduvad eesti keeles kahe prototüüpse funktsiooni, KAASNEMISE ja VASTASTIKUSUSE ümber (joonis 1). Ülejäänud funktsioonid on neist tuletatud ja keskmest kaugemal. Osa neist väljendatakse tekstides komitatiiviga (omAndus, VAHEND, LIIKUMISVAHEND, VIIS, VÕRDLUS, AEG, SUHESTAMINE), osa aga põhiliselt muul viisil (ASJAOLU, TEGEVUSOBJEKT, NEUTRAAL). 


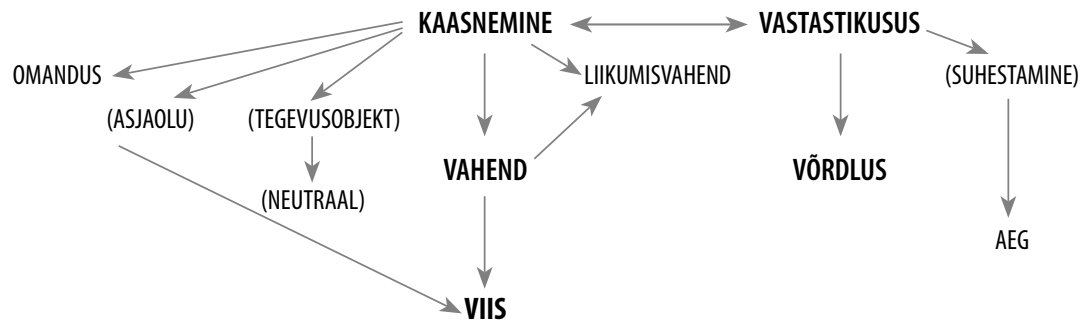

Joonis 1. Eesti komitatiivi funktsioonid

\section{Komitatiivi funktsioonid eri tekstiliikides}

Siinses jaotises analüüsime komitatiivi funktsioonide kasutust eri aegade erinevates tekstiliikides.

\section{1. Üldpilt}

Komitatiivil on kolm sagedast funktsiooni (joonis 2). Sagedasim on VAHEND, mis annab kokku 23\% kõigist komitatiivi kasutustest analüüsitud materjalis (lisa 1). Kaks prototüüpset funktsiooni KAASNEMINE ja VASTASTIKUSUS on sageduselt järgmised (vastavalt 16\% ja 15\%). Kokku annavad need kolm 54\% kõigist komitatiivi kasutustest. VASTASTIKUSUS esineb sealjuures tänapäeva tekstides oluliselt sagedamini kui KAASNEMINE (v.a netidialoogid). Vana kirjakeele tekstides on suhe vastupidine.

Komitatiivivormide statistika näitab, et eri perioodidel on funktsioonide kese erinev (lisa 1). 17.-18. sajandi komitatiivid koonduvad KAASNEMISE funktsiooni ümber. Sinna kuuluvad lisaks VAHEND, VIIS ja nende üleminekujuhtumid. 18. sajandi õpetlikus jutukirjanduses lisanduvad ka sama haru perifeersemad funktsioonid: TEGEVUSOBJEKT, ASJAOLU ja OMANDUS. Seevastu teine prototüüpne funktsioon VASTASTIKUSUS ning sellega seostuvad võRDLUS ja SUHESTAMINE ilmnevad alles 20. sajandi tekstides. KAASNEMISE rühma on tänapäeval lisandunud OMANDUS. AEg ilmub 18. sajandil, NEUTRAAL on olemas kogu analüüsitud aja vältel. 


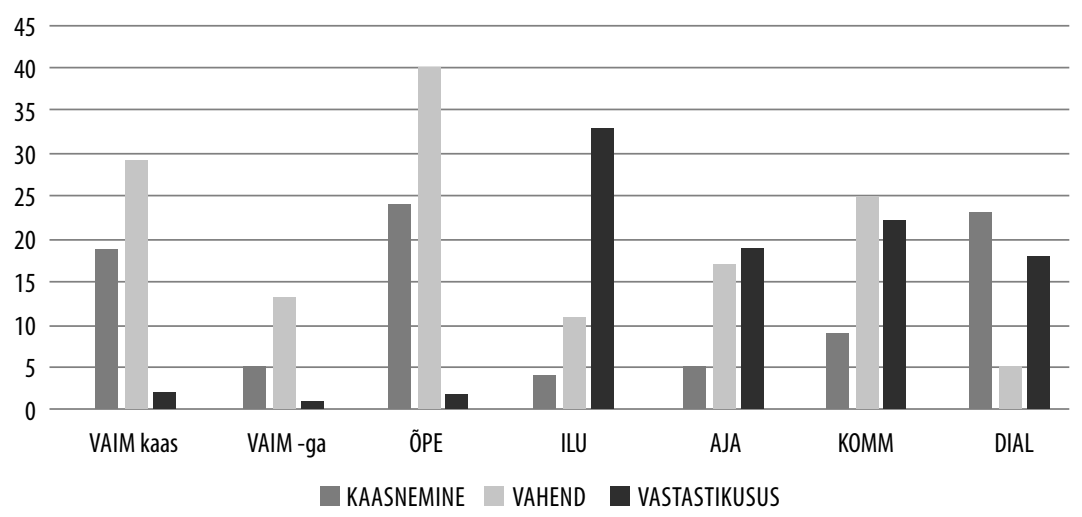

Joonis 2. Komitatiivivormide kolm keskset funktsiooni erinevates tekstiliikides

\subsection{Komitatiiv 17.-18. sajandi tekstides}

Järgnevalt käsitleme komitatiivsuse vormiliste väljendusvahendite varieerumist 17 . sajandi kirjakeeles ning vaatleme selle seost komitatiivi funktsioonidega (jaotis 6.2.1). 17.-18. sajandi usu- ja õpetlike tekstide komitatiivi funktsioone käsitleme koos, sest funktsioonide jaotumus on sarnane (jaotis 6.2.2).

\subsubsection{Komitatiivi vormivalikud 17.-18. sajandi usutekstides}

Komitatiivil on 17.-18. sajandi usutekstides kaks vormivarianti. 17. sajandil väljendatakse seda veel sõnaga kaas vormistatud kaassõnafraasi abil. See on põhiline väljendusvõimalus Georg Mülleri, Heinrich Stahli ja Christoph Blume tekstides. 18. sajandi algupoole usutekstides on juba täielikult üle mindud komitatiivi käändelõpuga väljendamisele (18. sajandi õpetlikes tekstides on kasutusel ainult käändelõpuga vormikuju).

Kaassõnafraasi abil väljendatakse komitatiivsust kõikides funktsioonides, mida on 17.-18. sajandi usutekstidest registreeritud. Sealjuures on kaassõnaline vorm ülekaalus käändelõpuga väljendatud komitatiiviga võrreldes (vt lisa 1).

Kuigi 17. sajandi esimese poole vaimulikel autoritel esineb teadaolevalt ka väga üksikuid kokku kirjutatud kaas-sõnaga ning lühenenud 
$k a$-kujulisi vorme, sattus siinsesse juhuvalimisse vaid üks selline erandlik vorm Georg Mülleri jutlustest - vIISI väljendav wèeka 'väega' (18). Võimalik, et siin on tegu erandliku leksikaliseeruva vormiga, mis on adverbi väga eelkäija.

(18) Ninck se sündi kuÿ Ihus keick neet Sanat olli teuthnut, heitotas hend se rachwas v̈lle tæma Oppetuße, minckprast tæma iütlis wėeka, ninck eb mitte ninda kuÿ neet Kiriateediat. (VAKK, Müller 1600)

Usutekstide komitatiivi vormivariantide võrdluses ilmneb, et kaassõnaliselt väljendusviisilt käändelõpu abil väljendamisele on ainsana kõige silmanähtavamalt üle läinud materjali hulgas sagedasim VAHENDI funktsioon. Samal ajal VIISI funktsiooni puhul muutust pole ja KAASNEMISE ning VAHENDI/VIISI rühm on uuenduse vastuvõtmisel pigem konservatiivsed.

Rööptekstides, kus on võimalik võrrelda eesti- ja saksakeelset kasutust, võib näha selget seost kaassõnafraasiga väljendatud komitatiivi ja saksa mit-prepositsioonifraasi vahel. Leidub vaid väga üksikuid kõrvalekaldeid, kus saksa keeles on kasutatud mõnd muud eessõna või struktuuri, vt (19) ja (20). Kõik sellised saksa ja eesti keeles vormilt erinevad näited on VAHENDI (kokku neli) või VIISI funktsiooni väljendamise kohta (kokku kaks). ${ }^{7}$

(19) Tema hing ellap igkawest Jummala jures / ke temma sihn selgke armo kahs / keickest pattust / ninck hexitussest / lebbi omma poja lunnastanut on. Sein Seele lebt ewig in GOtt / der sie allhie auß lauter Gnad / von aller Sünd vnd Missethat / durch seinen Sohn erlöset hat. (VAKK, Stahl 1637)

(20) Minna tahan puchta Wee kahs teid kastma / et teije puchtax sahte keikest teije Rojadussest nink keikest teije wörast Jummalast.. Jch wil rein Wasser über euch sprengen / das ihr rein werdet von aller euer Unreinigkeit und von allen euren Götzen wil Jch euch reinigen. (VAKK, Blume 1662)

7 Näites (19) on kasutatud VAHENDI funktsiooni väljendamiseks kaas-adpositsioonifraasi. See ei lange vormilt ühte saksakeelse fraasiga, mida võiks tõlkida 'selgest armust'. Ka näites (20) kasutatakse vAHENDI tähenduses komitatiivset kaassõnafraasi, mis ei ühti vormilt saksa tekstis väljendatud fraasi loogikaga (tõlkes: tahan puhta vee teie üle piserdada). 


\subsubsection{Komitatiiv 17.-18. sajandi kirjakeeles}

Komitatiivi funktsioonidest on nii 17. kui ka 18. sajandi tekstivalimis ühtlaselt sagedasim VAHEND (21), vastavalt 42 ja 40 esinemiskorda. Järgneb KAASNEMISE funktsioon, mida leidub nii 17. kui ka 18. sajandi tekstides võrdselt 24 korral (22). Sageduselt kolmas on vIIS, mis samuti esineb usu- ja õpetlikes tekstides võrdselt (12/12) (23). Sagedaste funktsioonide võrdne esinemus osutab väljakujunenud kasutusmustritele ja neist sagedamate juurdumisele kirjakeeles. See näitab vanema kirjakeele traditsiooni püsivust koosesinemise väljendamisel.

(21) Sinna ep ole mo Pääd Ölliga woidnud / ja temma on minno Jalgo Salwiga woidnud. (VAKK, UT 1715)

(22) Röhmustaket hend nende röhmsade kahs / ninck nutket / nende nuttijade kahs. Frewet euch mit den Frölichen / vnd weinet mit den Weinenden. (VAKK, Stahl 1638)

(23) Eth meije keickest süddamest woime / perrast röhmo kahs tennama / sünd kuhlma sünno sanna perrast / sünd kihtma sihn / ninck sehl iggawest. Auff daß von Hertzen können wir / nachmahls mit frewden dancken dir / gehorsam seyn nach deinem Wort / dich allzeit preysen hie vnd dort. (VAKK, Stahl 1637)

17. sajandi tekstides on eraldi märgendatud VAHENDI/VIISI üleminekurühm (17 juhtu), kuhu kuuluvad näited iseloomustavad kahe funktsiooni vaheala. Suu ja keel võivad näites (24) olla küll jumala kiitmise vahendiks, kuid lause žanriomast kujundlikku tõlgendust arvestades väljendavad ühtlasi kiitmise verbaalset viisi.

(24) Kudt meÿe hend nüit süddamest röimustame, Su ninck Kele kaas Iumala kÿtame. (VAKK, Müller 1601)

Kõik ülejäänud funktsioonid on mõlemas tekstirühmas tunduvalt harvem esindatud (vt lisa 1). Spetsiifilised funktsioonid NEUTRAALNE OSALINE ja VASTASTIKUSUS tulevad esile 17.-18. sajandi usutekstides ning ASJAOLU, OMANDUS ja TEGEVUSOBJEKT lisanduvad alles 18. sajandi õpetlikes tekstides. Haruldasematest funktsioonidest on 18. sajandi õpetlikes tekstides esindatud AEG (25) ja LIIKUMISVAHEND (26), mõlemad ühe näitega. 
(25) Se jook ei woi aitada kahte ehk kolme päwaga, waid sinna pead sedda joma kaua. (VAKK, Hupel 1766)

(26) Ta teist korda käisid nemmad kahhekeste wankriga ommad suggulassed kuulma. (VAKK, Willmann 1782)

\subsection{Komitatiiv 20.-21. sajandi ilu- ja ajakirjandustekstides}

20.-21. sajandi tekstidest olid vaatluse all ilukirjandus- ja ajakirjandustekstid, mille komitatiivi kasutuses on mitmesuguseid erinevusi (lisa 1).

Ilukirjandustekstides domineerib vASTASTIKUSUS, mida esindab kolmandik kasutustest (33 juhtu). Ilukirjandus käsitleb ennekõike inimsuhteid ja nii on siin oluline koht inimeste vastastikustel tegevustel ja suhetel, mida väljendavad verbid ja ühendid suhtlema, tuttavaks saama, kohtuma, kokku juhtuma, juttu ajama, (kellegagi) rääkima, vaidlema, kemplema (näited 27, 28)

(27) Kui kohtud minuga, kohtud kõigiga. (ILU)

(28) Nii ütles mulle ema, kui ta veel minuga rääkis. (ILU)

Suhteliselt sage on ka võRduus (12 juhtu). Kõrvutusi leidub peamiselt tekstide kirjeldavates osades, kõrvutatavad entiteedid võivad olla mitut tüüpi: inimesed, elusolendid, kehaosad, loodusobjektid jne (vrd näited 29 ja 30).

(29) Kuid arvamusvabadust pole mul ometi: ma ei tea, kes Vilma õieti on, ja ma ei saa igale vastutulijale jutustada oma elulugu, mis on mul emaga sündimise fakti läbi ühine. (ILU)

(30) Ta küsis, kas olen märganud, et kastani just-just lahtiminevad lehed sarnanevad noorte kotkaste veel munamärgade tiivanukkidega. (ILU)

Üle kümne korra esines veel vAHENDIT (11 korda, näited 31 ja 32) ja VIISI (10 korda, näide 33). Vahendiks on eluta objektide (nagu käterätik, näide 31) kõrval ka tegevused, nagu pilk või teade (näide 32).

(31) Sina olid ka siis juba olemas, tõmbasin kõhu käterätikuga kõvasti kinni, et sa ei segaks, ja nii ma siin kündsin ja külvasin, nii et kui vanamees vangilaagrist tuli, oli mõnigi põld sootuks teistsugune. (ILU) 
(32) Vana naine jälgib mind üle laua terase huvitatud pilguga ning ütleb siis: Vilma oli väga julge naine. (ILU)

(33) Taipasin oma teguviisi tähendust sel hetkel, kui ema täiesti kainestavalt rahuliku häälega teatas, et mu vanatädi - ka ju Reiter - olevat alati toonitanud (ema sõna!), et nõid ei tohi kedagi needa, needus tulevat talle endale kätte. (ILU)

Analüüsitud ajakirjandustekstid käsitlevad peamiselt ühiskonnaelu ja töö temaatikat. Selles tekstiliigis tõuseb esile kolm üsna võrdse sagedusega esindatud funktsiooni: VASTASTIKUSUS (19 juhul), VAHEND (17 juhul), OMANDUs (17 juhul), mis peegeldavad hästi ajalehetemaatika eri tahke.

Vastastikust tegevust märgivad verbid nagu suhtlema, pahuksisse minema, samuti nimisõnad nagu konflikt, kontakt, leping, kohtumine (näited 34, 35).

(34) Aga ta suhtleb oma endise kaasaga edasi. (AJA)

(35) Jah, mul on märtsis kavas kohtumine haridusministriga. (AJA)

Vahenditeks on nii tegevused (36), kehaosad (37) kui ka konkreetsed töövahendid (38).

(36) Riik loodab seaduserikkujad tööga ümber kasvatada. (AJA)

(37) Paar päeva varem olid esimesed konnad kraavivette kudenud ja eelmisel ööl kudu külmumise eest kaitsnud, sebides jalgadega, et vesi ringleks. (AJA)

(38) Põhimõtteliselt on võimalik hea foto saada ka ühekordseks kasutamiseks mõeldud aparaadiga, samuti nn seebikarbiga. (AJA)

Ajakirjandustekstides kasutatud OMANDUSE näited sarnanevad ilukirjanduses leiduvate kirjeldavate täienditega (39), samas leidub ka mitmesuguseid termineid (40).

(39) Erakordselt hea huumoriga mees. (AJA)

(40) Käesolevast aastast ei määrata puuetega lastele enam transpordi- ja telefoni kasutamise toetust, see-eest suurendati puudega lapse toetust: keskmise puudega lapsele makstakse nüüd 860 krooni, raske ja sügava puudega lapsele 1020 krooni. (AJA) 


\subsection{Komitatiiv netitekstides}

Netitekstide hulgast oli analüüsiks valitud kaks väga tavalist netisuhtluse varianti: netikommentaarid ja spontaansed dialoogid. Need tekstiliigid erinevad sagedasima funktsiooni poolest, kuid sarnanevad muude sagedamini kasutatud funktsioonide poolest.

Netikommentaaride temaatika on lai ning selle määravad enamasti netiportaalide ajakirjanikud, vähem kommenteerijad ise, kes võivad küll liikuda oma kommentaarides lähteteksti teemast eemale. Kommentaarides domineerivad kaks funktsiooni: vAHEND ( 25 juhtu) ja VASTASTIKUSUS (22 juhtu), mis annavad kokku ligi poole komitatiivivormidest. VASTASTIKUSUSE puhul on tavalised inimeste suhteid ja vastastikust tegevust väljendavad verbid (suhtlema, rääkima, kokku leppima, koostööd tegema, kokku puutuma, kampa lööma jms) (41). VAHENDIKS (42) on üldjuhul elutud objektid (kasevits, kraadiklaas, masuut, fritüüriõli jms). Tegevused on siin harvad (maksutõus, propaganda, riigipööre). Kümme korda esines veel omANDus (43).

(41) te lö̈te Meelis Paiga kampa ja siis veel kurdate? (KOMM)

(42) Laipu toodetakse ikka tinaga mitte kummiga. (KOMM)

(43) Närvilistele või imestavatele teadmiseks, et tegemist on sisepõlemismootoriga laevaga, suits/tahm on selliseljuhul täiesti normaalne. (KOMM)

Kommentaaride statistikat analüüsides tuleb arvestada, et üldjuhul on tegemist mõnelauseliste tekstidega, mis keerlevad ümber kindla teemakeskme. Kui selleks keskmeks on nt VAHEND, siis hakkab see korduma kas sama märksõnana või sünonüümidena (nt analüüsitud tekstides kraadiklaas ja kütus). See mõjutab väikeste arvude juures statistikat.

Netidialoogides on peamiseks jututeemaks möödunud või tulevased sündmused. Räägitakse sellest, mida kellegagi koos tehti või mida plaanitakse koos teha. Siin on komitatiivi funktsioonidest ülekaalus KAASNEMINE (23 juhtu) ja VASTASTIKUSUS (18 juhtu) (näited 44 ja 45). Kümne korrani ulatusid veel OMANDUS ja LIIKUMISVAHEND (46), (47).

(44) mm, mõtlesin et tulen siis koos teiega äkki tartu pühapäeval (DIAL)

(45) peaks Üllariga ka sellest rääkima ja mis ta arvab jne. (DIAL) 
(46) nt ostad jalgpallimustriga läätsed endale (DIAL)

(47) tegelt ma tulen raudselt bussiga (DIAL)

\section{Komitatiivi süntaktilised vormitüübid}

Sama tähendusfunktsioon võib olla väljendatud süntaktiliselt lause või fraasi tasandil. Näiteks võRDLus võib olla lausemäärus (tütar sarnaneb emaga), infiniitfraasi sisene määrus (emaga sarnanev tütar), adjektiivifraasi sisene määrus (tütar on emaga sarnane) või täiend (tütre sarnasus emaga). Meie analüüs tõi välja seitse komitatiivi süntaktilist vormitüüpi, mis koonduvad kahte rühma.

1. Lause vahetud liikmed: (a) lausemäärus, mis laiendab predikaati (48) ja (b) öeldistäide (49).

(48) Siis saabki see kasiinosaar EOK rahadega valmis... (KOMM)

(49) Tema looming olid õrn, valus, ja poeetiliselt kõrge tundlikkusastmega kuni kõige viimaste tekstideni välja. (KOMM)

Fraasiliikmed: (a) nimisõnafraasi sees olev täiend (50), (b) adjektiivifraasisisene määrus (51), (c) adverbifraasisisene määrus (52), (d) kaassõnafraasi sees kaassõna laiend (53), (e) infinitiivifraasi sees infiniitset verbivormi laiendav määrus (54).

(50) ja tead see rongiga ringreis oleks ka päris tore (DIAL)

(51) Üks naine - ja tingimata suurt kasvu - oli kangesti tahtnud temaga tuttavaks saada. (ILU)

(52) Maali koolnukange keha tõsteti üles ning ta aeda fikseerinud silmad suruti laugudega tasa. (ILU)

(53) Jõudu koos refirõivastega rahva seljas trampimiseks! (KOMM)

(54) ma lähen laupäeval rootsi kristiani vanematega kohtuma - aga ma ei ole seda veel vanematele rääkinud, niiet, ära ka räägi (DIAL)

Analüüs näitas (lisa 2), et kõigis tekstiliikides on komitatiivi keskseks vormitüübiks predikaati laiendav lausemäärus, mida on keskmiselt $66 \%$ komitatiivi kasutustest. Sealjuures on määruse osakaal vanas kirja- 
keeles suurem kui tänapäeva keeles (77-90\% vs. 50-64\%). Teine sagedane kasutus on nimisõnafraasi kuuluv täiend. Seda leidub vanas keeles minimaalselt (0-3\%), uues keeles oluliselt enam (13-29\%), sealjuures sagedamini ajakirjanduses. Sageduselt kolmas on infiniitset verbivormi laiendav määrus. Ka seda on vanas keeles vähem kui nüüdiskeeles (8-9\% vs. 9-24\%). Selle kasutus kõigub samuti, enim on seda netikommentaarides. Ülejäänud vormitüübid esinevad vaid üksikjuhtudel (alla kuue esinemisjuhu). Järgnevalt vaatame komitatiivi vormikasutusi tekstiliikide kaupa.

17. sajandi usutekstides on valik piiratud. $90 \%$ komitatiivivormidest on siin lausemäärused, üheksal korral esineb ka infinitiivimäärust (20).

(20) Minna tahan puchta Wee kahs teid kastma / et teije puchtax sahte keikest teije Rojadussest nink keikest teije wörast Jummalast .. (VAKK, Blume 1662)

18. sajandi õpetlikes tekstides lisandub vähesel määral erinevaid fraasilisi vormitüüpe, enim infinitiivifraase. Silma hakkab sagedase KAASNEMISE tähenduse väljendamine erinevate vahenditega. Märgata võib ka omapärast kasutust adpositsioonifraasi sees, mis on seotud 17.-18. sajandi kirjakeeles kasutusel olnud kaassõnaga ühtlasi $\sim$ ühtlase 'koos' (55). Õpetlikus jutukirjanduses hakkab silma OMANDusT väljendav öeldistäide (56).

(55) Kui tiwad peawad sisse jäma, siis raiu neid pissokessiks tükkiks, ja keeda neid ühtlase kannadega ülles. (VAKK, Lithander 1781)

(56) Mets pippar se kaswab metsas, se juur on kange maggusa haisoga; sellesamma rohho sees on suur wäggi .. (VAKK, Hupel 1766)

20. sajandi ilukirjandustekstides leidub mõnevõrra nimisõnafraasi ja infiniitse verbifraasi siseseid komitatiivivorme. Nimisõnafraasis märgib komitatiiv OMANDUST, eriti mitmesuguste tervikute osi (57).

(57) Ma olen suurte saalide ja avarate akendega hoonete inimene, ütles ta teinekord, ma armastan peegelseinu ja esivanemate rasketes raamides fotosid, kinnitas ta. (ILU)

Ilukirjandustekst ei ole eriti tihe ega sekundaartarindite rikas, hajusalt esineb erinevaid infiniitseid verbivorme (partitsiipe, infinitiive, konverbe), mida komitatiiv laiendab (58). 
(58) Surmal oli seljas pikk maani mantel, hästimääritud ja läikimalöödud linnamehe kingad, ja tal oli täiesti paljas valge ovaalse munaga sarnanev hiiglasepea. (ILU)

Ajakirjandustekstides kuulub komitatiiv ilukirjandustekstidest sagedamini fraasi koosseisu, põhjuseks asjaolu, et ajakirjandustekst on tihedam. Eriti palju (29 kasutust) on siin nimisõnafraasisiseseid täiendina esinevaid komitatiivivorme. Enamik neist väljendab omandussuhet (puudega laps, rahakohvritega mehed), kuid selle kõrval on ka nominalisatsioone, kus väljendatav funktsioon on tüüpiline pigem lausemäärusele, nt VAHEND (59) või KAASLANE (PARTNER) (kohtumine haridusministriga).

(59) Mina pean kohaliku tarbimise võimalikult täielikku rahuldamist toiduainetega ka Eesti põllumajanduse lähiaastate ülesandeks. (AJA)

Netikommentaarid on mõnevõrra kokkupakitud väljendusega, sarnanedes ajakirjandustekstidega. Infinitiivifraasi määrusi (60) on siin rohkem kui muudes tekstiliikides, palju on ka täiendeid nimisõnafraasis (61). Netikommentaarid ja ajakirjandustekstid sisaldavad ka vähim lausemäärusi (vastavalt 50 ja 52\%).

(60) Lubavad kahe tunniga kohal olla ja pidevalt vabandavad, et ilmastikuolud ei luba kihutada, hilineme pool tundi, taas. (KOMM)

(61) See ei erine KGB koostööst kriminaalidega nõukogude liidus. (KOMM)

Netidialoogid omakorda sarnanevad enim ilukirjandustekstidega. Täiendeid ja määrusi infinitiivifraasis on siin suhteliselt sama palju kui ilukirjanduses, samuti on suhteliselt sarnasel hulgal lausemäärusi.

\section{Koosesinemise väljendamisest muudes keeltes}

Koosesinemist väljendavad eri keeltes erinevad vahendid, mida saab võrrelda eesti komitatiiviga. Siin vaatame keeli, millel võiks olla seoseid eesti keelega. Võrdleme nende keelte komitatiivide funktsioonide võrgustikku eesti komitatiivi funktsioonidega (joonis 1), eeldades võrgustikku kujundavate funktsiooninihete suhete samalaadsust. Olulisim vana rahvusvaheline suur mõjukeel on saksa keel ning uusimal ajal inglise keel. Teisalt on eesti komitatiivil seosed läänemeresoome 
keeltega (ennekõike soome keel) ning mittesugulaskeeltest Läänemere areaali keeltega (läti, leedu, vene).

Koosesinemine, sealhulgas KAASLASE ja VAHENDI väljendusviiside kokkulangemine või erinemine, on mitme tüpoloogilise uurimuse teema, kus hõlmatud on ka Läänemere areaal (Stolz 2001, Stolz jt 2006, Heine ja Kuteva 2006). VAHENDI vormistamine KAASLASENA on alguse saanud romaani keeltest ja levinud järk-järgult mujale. Läänemere areaalis on see tõenäoliselt germaani keelte (saksa, taani, rootsi) eeskujul levinud balti, slaavi ja läänemeresoome keeltesse. Tänapäeval langevad VAHENDI ja KAASLASE vormistus kokku eesti (komitatiiv), läti (eessõna $a r$ koos nimisõna akusatiiviga), liivi (instrumentaal) ja saami keeles (komitatiiv), erinevad aga vene, soome ja poola keeles. Leedu keel viibib üleminekufaasis (VAHENDIT märgib instrumentaal, KAASLAST instrumentaal koos eessõnaga $s u$ ).

Järgnevalt vaatame konkreetsemalt saksa, läti, inglise, soome, vene ja leedu keelt.

Eesti keele kontaktkeeltest on koosesinemise eri tüüpidel üks universaalne väljendusviis saksa keeles, kus peaaegu kõiki koosesinemise funktsioone saab täita nimisõna koos eessõnaga mit (joonis 3). Erinevusi eesti ja saksa keele vahel on mõningates perifeersetes funktsioonides: LIIKUMISVAHEND võib saksa keeles olla väljendatud ka kohana; ASJAOLU väljendab pigem ühend eessõnaga durch, AEGA eessõna in. Lisaks on saksa mit-ühendil ka eesti essiiviga sarnane funktsioon (mit 15 Jahre '15-aastasena') (Lehmann ja Shin 2005).

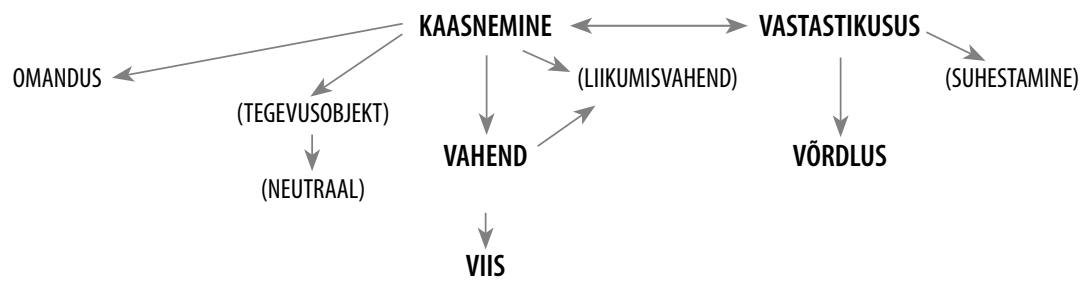

Joonis 3. Saksa mit-ühendi funktsioonid

Läti keeles väljendab koosesinemist eessõna ar koos akusatiiviga. $a r$-tarind väljendab KAASNEMIST, VAHENDIT, LIIKUMISVAHENDIT, VASTASTIKUSUST, OMANDUST, ei väljenda aga VIISI, ASJAOLU, AEGA, enamasti ka mitte VÕRDLUST, SUHESTAMIST, TEGEVUSOBJEKTI ega NEUTRAALI (joonis 4, info Ilze Tālbergalt). 

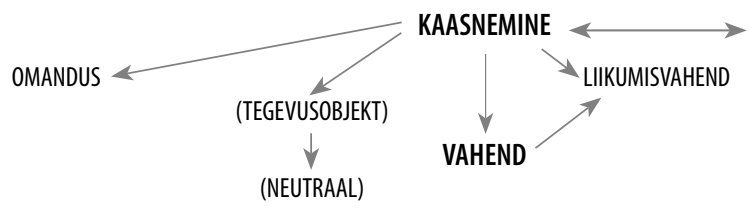

VASTASTIKUSUS

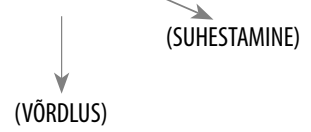

Joonis 4. Läti $a r$-ühendi funktsioonid

Inglise keeles on peamiseks koosesinemise väljendamise vahendiks eessõna with, mis täidab suurt osa ka eesti keele komitatiivile omastest funktsioonidest (joonis 5). KAASNEMIST, VASTASTIKUSUST, VAHENDIT, VIISI, ASJAOLU ja OMANDUST väljendatakse peamiselt (esimese kolme puhul peaaegu ainuvõimalikult) with abil. Mõnel määral võib with väljendada ka võRdLUST, SUHESTAMIST, TEGEVUSOBJEKTI või NEUTRAALSET OSALIST, kuid nendes funktsioonides esinevad ka teised eessõnad (nt to, on) ning erinevate eessõnade kasutus oleneb pigem verbi või omadussõna rektsioonist kui eessõnade enda tähendustest (nt $X$ is equal to $Y^{\prime} \mathrm{X}$ võrdub Y-ga', aga $X$ can be equated with $Y$ 'X-i võib pidada Y-ga võrdväärseks'). Erinevalt eesti komitatiivist ei kasutata eessõna with LIIKUMISVAHENDI Või AJA väljendamiseks (travel by/*with bus, finish the project in/*with a week).

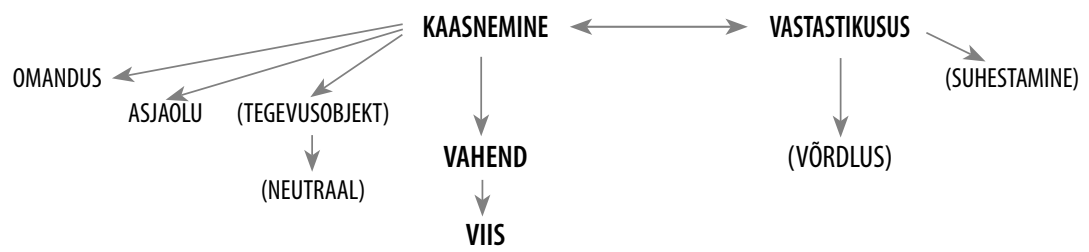

Joonis 5. Inglise with-ühendi funktsioonid

Vene keeles täidab enamikku koosesinemise funktsioonidest instrumentaal eessõnaga $s$ (joonis 6). VAHENDIT, aga osalt ka TEGEVUSOBJEKTI ja sUHESTAMIST väljendab instrumentaal ilma eessõnata. Erinev on ka LIIKUMISVAHENDI vormistamine kohaväljendiga ja ajalise kestuse vormistamine ühendiga, millesse kuulub eessõna $z a$. (Arkhipov 2009, Nikolina 2016) 


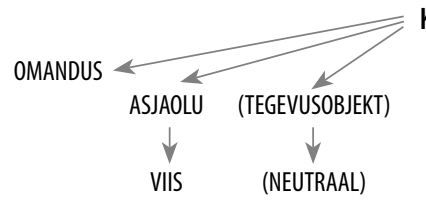

\section{KAASNEMINE}

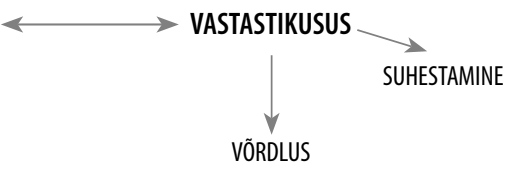

Joonis 6. Vene $s$-ühendi funktsioonid

Soome keeles on koosesinemise ühtne vormivahend kujunemata. Vana ine-komitatiivi ${ }^{8}$ funktsioonid (joonis 7) on ahenemas, levib ühend kaassõnaga kanssa (joonis 8), kuid mõlema funktsioonid on suhteliselt piiratud. VAHENDIT märgib soome keeles adessiiv, muid funktsioone täidavad mitmesugused kohakäändevormid. kanssa-tarind väljendab KAASNEMIST, VASTASTIKUSUST, VÕRDLUST, vahel ka TEGEVUSOBJEKTI, inekomitatiiv KAASNEMIST, OMANDUST, mõnevõrra ka VAHENDIT ja TEGEVUSовJEкTI (Kingisepp 1992, Remes 2015: 329-330, Sirola-Belliard 2016).

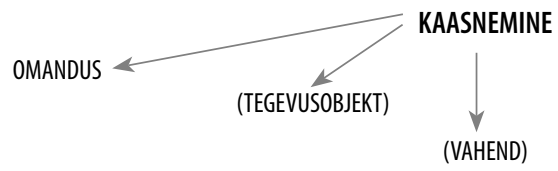

Joonis 7. Soome ine-komitatiivi funktsioonid

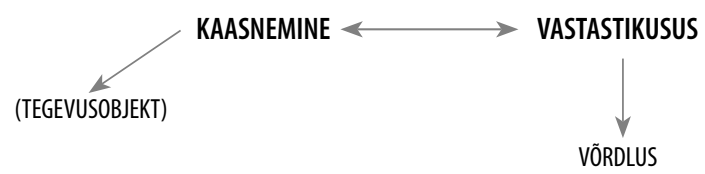

Joonis 8. Soome kanssa-tarindi funktsioonid

Leedu keeles märgib vAHENDIT instrumentaal, KAASLAST instrumentaal koos eessõnaga $s u$. Leidub aga ka kasutusjuhte, kus $s u$ on rõhutavana lisatud VAHENDIT märkivale instrumentaalile (Heine ja Kuteva 2006, Stolz 2001). Lisaks KAASLASELE saab kaassõnatarind $s u+$ instrumentaal täita enamikku koosesinemise funktsioonidest, märkides nii KAASLAST kui ka VASTASTIKUSUST, esiletõstu korral ka LIIKUMISVAHENDIT,

8 Soome keeles kasutatakse terminit ine-komitatiiv, sest vormi koosseisu kuulub alati ka mitmuse tunnus $i$. 
ühe võimaliku vormistusviisina ka vÕRDLUST, ASJAOLU, VIISI, OMANDUST, TEGEVUSOBJEKTI, NEUTRAALI ja SUHESTAMIST (joonis 9). Ilma kaassõnata instrumentaal (joonis 10) väljendab vAHENDIT ja LIIKUMISVAHENDIT (viimane tundub olevat kahe vormivahendi ühenduslüliks), ka TEGEVUSOBJEKTI. (Info Milda Dailidènaitèlt.)

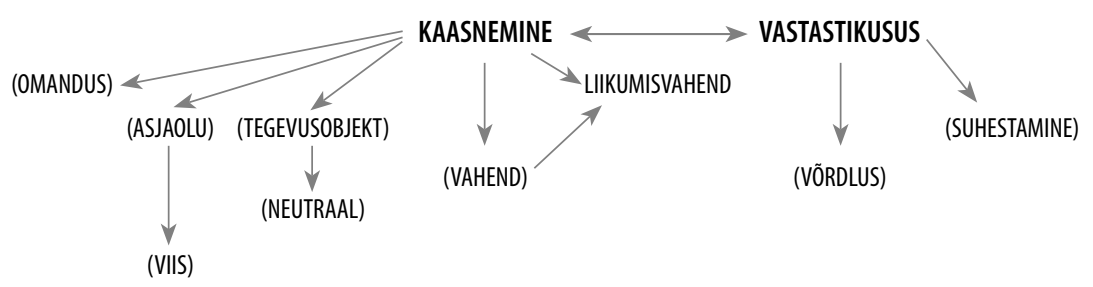

Joonis 9. Leedu $s u$-tarindi funktsioonid

(TEGEVUSOBJEKT) — VAHEND — LIKUMISVAHEND

Joonis 10. Leedu instrumentaali funktsioonid (ilma kaassõnata)

\section{Kokkuvõtteks}

Siinses käsitluses eristasime komitatiivi 12 funktsiooni. Osa neist leidub ka erinevates varasemates eesti komitatiivi funktsioonide kirjeldustes. Sellised on KAASNEMINE, VAHEND, VIIS, OMANDUS, AEG, TEGEVUSOBJEKT ja ASJAOLU. Lehmanni ja Shini (2005) järgides oleme eristanud veel LIIKUMISVAHENDI ja VASTASTIKUSUSE. Lisaks oleme tõlgendanud eraldi funktsioonidena võRDLUST, SUHESTAMIST ja NEUTRAALSET OSALIST, mida ei leidu Lehmanni ja Shini loendis ning mis eesti materjalis on varem välja toodud üksnes määruste all.

Eesti suhteliselt noor komitatiiv on muude keelte taustal tüüpiline komitatiiv, mis täidab peaaegu kõiki Lehmanni ja Shini esitatud koosesinemise funktsioone. Koosesinemise funktsioonid moodustavad võrgustiku, millel on kaks keset, kaks prototüüpset komitatiivi funktsiooni: KAASNEMINE ja VASTASTIKUSUS. Ülejäänud funktsioonid on ühest või teisest kesksest funktsioonist otseselt või kaudselt tuletatavad.

Komitatiivi funktsioonid 17.-18. kirjakeeles esindavad KAASNEMISE haru (tuletatud funktsioonideks on VAHEND ja VIIS); 20. sajandi materjalis domineerib VASTASTIKUSUS ja sellest tulenevad funktsioonid (VõRdLUS, SUHESTAMinE). KAASLASE ja VAHENDI kokkulangevus on 
Balti areaali joon, mis oli olemas juba ajaloolisel $n e$-komitatiivil, mis on praegusel soome ine-komitatiivil ja mille võttis üle ka eesti keeles kujunev uus komitatiiv. Uue komitatiivi kujunemisel 17.-18. sajandil oli VAHENDI funktsiooni grammatiseerumine KAASLASE funktsioonist varasem. Komitatiivi funktsioonid on sajandite jooksul järjest laienenud. Perifeersemates funktsioonides täidab komitatiiv juba grammatiliste käänete funktsioone, vormistades mitte-esiletõstetuna lause keskseid argumente.

Tänapäeva kirjakeele materjalis on esindatud nii komitatiivi KAASLASE kui ka VASTASTIKUSUSE haru, kasutusvõimalused on laiad ning kasutustendentsid seostuvad tekstiliigi funktsionaalse ja sisulise eripäraga: ilukirjanduses tõuseb esile VASTASTIKUSUS, ajakirjanduses VAHEND ja fraasisisesed komitatiivid teksti tiheduse ilminguna. VAHEND tõuseb esile ka netikommentaarides, kus arutletakse mingite tööde-toimingute üle, netidialoogides aga kaasneb ühise tegutsemise temaatikaga KAASLASE rolli esiletõus. Kui vaadelda võrdluseks soome kahe komitatiivi funktsioone (Sirola-Belliard 2016), siis sealgi on KAASNEMISE funktsioon vanem kui vaSTASTIKUSUS. Soome vana ine-komitatiiv vaSTASTIKUSUST ei väljenda, uus kanssa-komitatiiv väljendab aga nii KAASNEMIST kui ka VASTASTIKUSUST.

Eesti keeles tekkis vana komitatiivi asemele juba vana kirjakeele perioodil uus kaasnemist väljendav komitatiivitarind, mis ennekõike hakkas toimima vana komitatiivi sarnaselt, aga kirjakeeles tõenäoliselt saksa mit-komitatiivi eeskujul levides võttis funktsioone järjest juurde.

Kontaktkeeltest sarnaneb eesti komitatiivi funktsioonivõrgustik enim saksa keele ja vähim soome keele võrgustikuga. Tõenäoliselt toetas saksa eeskuju eesti keeles kujunenud komitatiivi funktsioonivõrgustiku kujunemist, mis võis alata juba kaas-tarindi kasutamise ajal. Ka suhteliselt perifeersed funktsioonid nagu TEGEVUSOBJEKT (alustama millegagi - beginnen mit etwas) ja NEUTRAAL (kuidas temaga on? - wie steht es mit ihm?) on saksa keeles olemas. Samas võis uus vormivahend komitatiiv hakata elama oma elu ja levima järjest enamatesse ühenditesse ning hõlvata lisaks ajaloolisele komitatiivile ka hääbuva instruktiivi tähendusala, millest annavad tunnistust eesti komitatiivi ja soome instruktiivi vastavused tõlkes (Kingisepp 1992: 20).

Eesti komitatiivi polüfunktsionaalsust tõstab esile võrdlus soome keelega, kus eesti komitatiivil on väga mitmesuguseid vasteid (Kingisepp 1992, Remes 2015). Eesti komitatiivi soome vastete rohkuse kohta annab Jaan Krossi tõlkimise kogemuse põhjal tabava iseloomustuse Juhani Salokannel: “... komitatiivi on juuri tällainen [viroa ja suomea] 
erottava tekijä, ja sen aiheuttama vaiva tuntuu minusta yksinomaan vapauttavalta ja positiiviselta. Viron komitatiivi tuntuu meistä kompaktilta, tehokkaalta, ja juuri Kross ilmaisee sen avulla virkkeisiinsä vielä entistäkin enemmän materiaalia, oikkuja, mutkia ja yllätyksiä taikka sitten juristimaista perusteellisuutta. ... ihanteeni ja tavoitteeni lienee komitatiivin parissa ollut luoda mahdollisimman erilaisia, vaihtelevia ja tilanteen mukaisia ratkaisuja. Mikäli kaikki tapaukset on suomennettu samalla tavalla, olen epäonnistunut." (Juhani Salokandle kiri Evamaria Sahlmanile 13.12.1991, Sahlman 1992)

\title{
Õnnesoovid ja tänuavaldused
}

Õnnitleme Birutet!

Täname Milda Dailidènaitèt, Ilze Tālbergat ja anonüümset retsensenti abi ja kasulike märkuste eest.

Artikli valmimist on toetanud Euroopa Liit Euroopa Regionaalarengu Fondi kaudu (Eesti-uuringute tippkeskus) ning projektid PUT475 "Kirjakeele morfosüntaksi varieerumise integreeritud mudel: pilootuuring eesti keele näitel" ja EKKM14-340 "Eesti keele akadeemiline grammatika".

\author{
Aadress: \\ Helle Metslang, Külli Habicht, Tiit Hennoste, Anni Jürine, \\ Kirsi Laanesoo, David Ogren \\ Tartu Ülikool \\ Eesti ja üldkeeleteaduse instituut \\ Jakobi 2, IV korrus \\ 51014 Tartu, Eesti \\ E-post: helle.metslang@ut.ee
}

\section{Lühendid}

AJA - 21. sajandi ajakirjandustekstid, DIAL - 21. sajandi netidialoogid, ILU - 20. sajandi ilukirjandustekstid, KOMM - 21. sajandi netikommentaarid, VAIM - 17.-18. sajandi usutekstid, ÕPE - 18. sajandi opetlikud tekstid 


\section{Kirjandus}

Arkhipov, Alexandre (2009) "Comitative as a cross-linguistically valid category". In Patience Epps and Alexandre Arkhipov, eds. New challenges in typology. Transcending the borders and refining the distinctions, 223-246. Berlin: Mouton de Gruyter.

EKG I = Mati Erelt, Reet Kasik, Helle Metslang, Henno Rajandi, Kristiina Ross, Henn Saari, Kaja Tael ja Silvi Vare (1995) Eesti keele grammatika I. Morfoloogia. Sõnamoodustus. Peatoim Mati Erelt, toim Tiiu Erelt, Henn Saari ja Ülle Viks. Tallinn: Eesti Teaduste Akadeemia Eesti Keele Instituut.

EKG II = Mati Erelt, Reet Kasik, Helle Metslang, Henno Rajandi, Kristiina Ross, Henn Saari, Kaja Tael ja Silvi Vare (1993) Eesti keele grammatika II. Süntaks. Lisa: Kiri. Peatoim Mati Erelt, toim Tiiu Erelt, Henn Saari ja Ülle Viks. Tallinn: Eesti Teaduste Akadeemia Keele ja Kirjanduse Instituut.

Ehala, Martin (1996) "Integreeritud keeleteooria võimalikkusest tänapäeva keeleteaduses (II)". Keel ja Kirjandus 6, 375-384.

Erelt, Mati (2008) "Concerning the relationship of the comitative construction to the coordinating construction in Estonian”. Linguistica Uralica XLIV, 2, 97-107.

Erelt, Mati ja Helle Metslang, toim (2017) Eesti keele süntaks. (Eesti keele varamu 3.) (Ilmumas.)

Erelt, Mati (2017) “Rinnastus”. Mati Erelt ja Helle Metslang, toim. Eesti keele süntaks. (Ilmumas.)

Habicht, Külli (2000) “Grammaticalization of adpositions in Old Literary Estonian”. In Mati Erelt, ed. Estonian: Typological Studies IV, 19-58. (Tartu Ülikooli eesti keele õppetooli toimetised 14.) Tartu.

Heine, Bernd and Tania Kuteva (2006) The changing languages of Europe. Oxford: Oxford University Press.

Kingisepp, Valve (1992) "Eesti komitatiivi tõlkevasted soome keeles". Maia Väkram, toim. Folia fennistica \& linguistica. Lähivertailuja 5. Suomalais-virolainen kontrastivinen seminaari Virroilla 27. ja 28. syyskuuta 1991, 15-28. (Tampereen yliopiston suomen kielen ja yleisen kielitieteen laitoksen julkaisuja 15.) Tampere.

Lakoff, George ja Mark Johnson (2011 [1980]) Metafoorid, mille järgi me elame. (Gigantum Humeris.). Tlk Ene Vainik. Tallinn: Tallinna Ülikooli Kirjastus.

Lehmann, Christian and Yong-Min Shin (2005) "The functional domain of concomitance. A typological study of instrumental and comitative relations." In Christian Lehmann, ed. Typological studies in participation, 9-104. (Studia Typologica 7.) Berlin: Akademie.

Nikolina, Julia (2016) Èstonskij komitativ i russkij tvoritel'nyi padež. Seminarskaja rabota. Narvskij kolledž Tartuskogo universiteta. Narva.

Remes, Hannu (2015) Viron kielioppi. Helsinki: Finn lectura.

Rätsep, Huno (1978) Eesti keele lihtlausete tüübid. Tallinn.

Rätsep, Huno (1979) Eesti keele ajalooline morfoloogia II. Tartu.

Sahlman, Evamaria (1992) Viron ga-komitatiivin käännösvastineet ja niiden semanttinen sisältö. Pro gradu -työ. Jyväskylä. 


\section{Helle Metslang, Külli Habicht jt}

Sakamoto, Mayumi (1995) Kaasaütlevas käändes atribuudi asendist tänapäeva eesti keeles. Magistritöö. Käsikiri Tartu Ülikooli eesti ja üldkeeleteaduse instituudis.

Siegl, Florian and Petar Kehayov (2010) Concomitance in Finno-Ugric - a preliminary comparative-typological study. (Ettekanne FU kongressil Piliscsabas.)

Sirola-Belliard, Maija (2016) Suomen komitatiivi. -ine ja kanssa. Tampere: Tampere University Press.

Stassen, Leon (2000) “AND-languages and WITH-languages”. Linguistic Typology 1, $1-54$.

Stolz, Thomas (2001) "On Circum-Baltic instrumentals and comitatives: To and fro coherence". In Östen Dahl and Maria Koptjevskaja-Tamm, eds. The CircumBaltic languages: Typology and contact. Vol. 2: Grammar and typology, 591-612. (Studies in Language Companion 55.) Amsterdam: Benjamins.

Stolz, Thomas, Cornelia Stroh, and Aina Urdze (2006) On comitatives and related categories: A typological study with special focus on the languages of Europe. (Empirical approaches to language typology 33.) Berlin: Walter de Gruyter.

Valgma, Johannes ja Nikolai Remmel (1968) Eesti keele grammatika. Käsiraamat. Tallinn: Valgus.

Vals, Helju (1953) Kaasaütlev kääne eesti keeles. Diplomitöö. Käsikiri Tartu Ülikooli eesti ja üldkeeleteaduse instituudis.

\section{Keelekogud}

Vana kirjakeele korpus: http://www.murre.ut.ee/vakkur/Korpused/

Tekstikorpused: https://keeleressursid.ee/et/keeleressursid/tekstikorpused 


\section{Lisa 1. Komitatiivivormide funktsioonid erinevates tekstiliikides}

\begin{tabular}{l|r|r|r|r|r|r|r|r} 
Funktsioon & \multicolumn{2}{|c|}{ VAIM } & ÕPE & ILU & AJA & KOMM & DIAL & KOKKU \\
\hline Kaas & $-g a /-k a$ & & & & & & \\
\hline KAASNEMINE & 19 & 5 & 24 & 4 & 5 & 9 & 23 & 89 \\
\hline VAHEND & 29 & 13 & 40 & 11 & 17 & 25 & 5 & 140 \\
\hline LiIKUMISVAHEND & & & 1 & 3 & 1 & 3 & 10 & 18 \\
\hline VAHEND/VIIS & 15 & 2 & & & & 1 & & 18 \\
\hline VIIS & 9 & 3 & 12 & 10 & 7 & 7 & 5 & 53 \\
\hline VASTASTIKUSUS & 2 & 1 & 2 & 33 & 19 & 22 & 18 & 97 \\
\hline VõRDLUS & & & & 12 & 7 & 4 & 2 & 25 \\
\hline SUHESTAMINE & & & & 3 & 5 & 2 & 9 & 19 \\
\hline TEGEVUSOBJEKT & & & 4 & 9 & 9 & 3 & 9 & 34 \\
\hline AsJAOLU & & & 6 & 1 & 2 & 4 & 1 & 14 \\
\hline OMANDUS & & & 6 & 7 & 17 & 10 & 10 & 50 \\
\hline AEG & & & 1 & 1 & 4 & 3 & 2 & 11 \\
\hline NEUTRAAL & 1 & 1 & 4 & 6 & 6 & 5 & 6 & 29 \\
\hline Muu & & & & & 1 & 1 & & 2
\end{tabular}

\section{Lisa 2. Komitatiivivormide süntaktilised vormitüübid}

\begin{tabular}{l|l|r|r|r|r|r|r|r}
$\begin{array}{l}\text { Koht } \\
\text { moodustus- } \\
\text { struktuuris }\end{array}$ & $\begin{array}{l}\text { Lause- } \\
\text { liikmelisus }\end{array}$ & VAIM & ÕPE & ILU & AJA & KOMM & DIAL & Kokku \\
\hline \multirow{2}{*}{$\begin{array}{l}\text { Lause- } \\
\text { liikmed }\end{array}$} & Määrus & 90 & 77 & 61 & 52 & 50 & 64 & 394 \\
\cline { 2 - 9 } & Öeldistäide & & 5 & 1 & 3 & 2 & 4 & 15 \\
\hline \multirow{2}{*}{$\begin{array}{l}\text { Fraasi- } \\
\text { liikmed }\end{array}$} & $\begin{array}{l}\text { Täiend nimi- } \\
\text { sõnafraasis }\end{array}$ & & 3 & 15 & 29 & 19 & 13 & 79 \\
\cline { 2 - 9 } & $\begin{array}{l}\text { Määrus } \\
\text { adjektiivifraasis }\end{array}$ & & 1 & 6 & 2 & & 2 & 11 \\
\cline { 2 - 8 } & $\begin{array}{l}\text { Määrus } \\
\text { adverbifraasis }\end{array}$ & & 1 & 1 & 1 & & & 3 \\
\cline { 2 - 8 } & $\begin{array}{l}\text { Määrus } \\
\text { infinitiivifraasis }\end{array}$ & 9 & 8 & 14 & 9 & 24 & 11 & 75 \\
\cline { 2 - 9 } & $\begin{array}{l}\text { Kaassona laiend } \\
\text { kaassõnafraasis }\end{array}$ & 1 & 5 & 2 & 4 & 4 & 6 & 22 \\
\cline { 2 - 9 } & Muu & & & & & 1 & & 1
\end{tabular}




\begin{abstract}
Helle Metslang, Külli Habicht, Tiit Hennoste, Anni Jürine, Kirsi Laanesoo, David Ogren: Functions of the comitative in different periods and registers of written Estonian. The various types of concomitance expressed by the Estonian comitative form a network, at the center of which are the two prototypical functions of the comitative, ACCOMPANYING and RECIPROCALITY. In the 17th-18th century written language, the comitative primarily expressed ACCOMPANYING and similar meanings, while the RECIPROCALITY function dominates in 20th-century texts. The functions of the comitative have grown broader over time. In more peripheral functions, the comitative even performs the functions of grammatical cases, encoding non-foregrounded core arguments - the semantics of the comitative have become blurred, and the grammatical relations it expresses have become less well defined. In the modern written language, both the COMPANION and the RECIPROCALITY branches are well-represented. Usage tendencies are tied to the functional and contentrelated characteristics of different text types: RECIPROCALITY is particularly common in fiction texts, while print media texts extensively utilize the INSTRUMENT function and often feature phrase-internal comitatives, illustrating their high textual density. In online comment sections the INSTRUMENT function is particularly prominent, while in MSN dialogues the COMPANION function stands out. Among contact languages, the network of functions of the Estonian comitative most closely resembles that of German and least closely resembles that of Finnish.
\end{abstract}

Keywords: comitative, concomitance, variation, register, written language, Estonian 